\title{
Lika Liku Kesuksesan Air Traffic Flow Management \\ di Bandara Internasional I Gusti Ngurah Rai
}

\author{
Bara Jiwangganata $M^{(1)}$ \\ I Gede Sanica ${ }^{(2)}$ \\ Universitas Pendidikan Nasional (1)(2) \\ baraatcbali@gmail.com ${ }^{(1)}$ \\ gede_sanica@yahoo.com ${ }^{(2)}$
}

\begin{abstract}
This research aims to determine and examine mountainously about the satisfaction of airlines and Perum lppnpi management through of air traffic flow management in I Gusti Ngurah Rai International Airport. This research used qualitative method with research subject namely airline, ATFM Operator and Perum lppnpi management. Data collection technique was carried out by in-depth interview. Researchers implement the adoption Zeithaml and Bitner's Servqual Technique. The result of data analysis in this study indicate that the quality of service through ATFM are well guarded, but significantly factor of that quality is reliability, why? Because the consumer has been satisfied with a good service, fast and punctuality.
\end{abstract}

Keywords: ATFM; Service Quality; Air navigation; Airlines; Airport

\begin{abstract}
ABSTRAK
Penelitian ini bertujuan untuk mengetahui dan mengkaji lebih dalam mengenai bagaimana kepuasan maskapai penerbangan dan manajemen Perum LPPNPI terhadap air traffic flow management di Bandara Internasional I Gusti Ngurah. Penelitian ini menggunakan metode kualitatif dengan subjek penelitian yakni maskapai penerbagan, operator ATFM, dan manajemen perum LPPNPI. Teknik pengumpulan data dilakukan dengan wawancara mendalam. Peneliti menggunakan teknik Servqual milik Zeithaml dan Bitner. Hasil analisis data pada penelitian ini menunjukkan bahwa kualitas pelayanan melalui Penelitian ini menggunakan teknis SERVQUAL yang menunjukkan bahwa segala aspek kualitas pelayanan ATFM sangatlah terjaga dengan baik, akan tetapi yang sangat berpengaruh untuk penelitian ini berdasarkan hasil wawancara adalah Reliabilty, mengapa demikian karena pengguna jasa dengan pelayanan yang ramah, cepat dan tepat waktu.

Kata Kunci: ATFM; Kualitas Layanan; Navigasi Udara; Maskapai penerbangan; Bandara
\end{abstract}

\section{PENDAHULUAN}

Seperti yang kita ketahui bersama, bahwa transportasi adalah sarana yang sangat membantu menghubungkan orang dengan yang lainnya, menurut KBBI transportasi adalah 1 pengangkutan barang oleh berbagai jenis kendaraan sesuai dengan kemajuan teknologi; 2 perihal (seluk- beluk) transpor; 3 pemindahan bahan lepas hasil pelapukan dan erosi oleh air, angin, dan es. Sarana transportasi yang digunakan untuk jarak jauh dan membutuhkan waktu yang relatif singkat adalah transportasi udara. Perpindahan penumpang dan barang yang 
membutuhkan kecepatan, ketepatan waktu, efisiensi, dan efektif membuat transportasi udara adalah pilihan utama bagi setiap orang. Saat ini pesawat udara yang menampung penumpang dan barang juga berkembang mengikuti teknologi, bahkan ada pesawat udara yang mampu mengangkut 800 penumpang, beberapa pesawat yang mampu menghemat bahan bakar, bahkan dengan teknologi ramah lingkungan, dan lain-lain. Tentunya akan berkembang sesuai kebutuhan yang diperlukan.

Selain alat transportasi udaranya, pemenuhan sarana prasarana tempat berlabuhnya yaitu Bandar Udara juga hendaknya mengikuti pesatnya pertumbuhan penumpang dan jenis jenis pesawat udara, bagaimana hendaknya pengelola Bandar udara memikirkan lahan parkir pesawat (apron), garbarata (aviobridge), dan tentunya juga terminal penumpang dan terminal kargo untuk barang pesawat udara. Disisi lainya pengelola navigasi penerbangan juga memikirkan daya tampung wilayah udara sehingga menghindari penumpukan di jam jam padat dan bisa lebih mengedepankan alur yang mengurangi penundaan, dan menciptakan keseimbangan antara pertumbuhan pesawat udara dan kapasitas Terminal Bandar udara (Yudhistira dan Darma, 2020; Darma dan Noviana, 2020; Priskila dan Darma, 2020; Shavitri dan Darma, 2020; Sudiwedani dan Darma, 2020; Handayani dan Darma, 2021).

Bandar Udara Internasional I Gusti Ngurah Rai merupakan salah satu Bandar Udara padat dan termasuk sibuk di indonesia. Karena hal itulah pengaturan pertumbuhan pesawat dan kemampuan terminal haruslah diatur supaya mampu mengalirkan arus penumpang dan barang secara lancar (Widana dan Darma, 2018; Dewi dan Darma, 2017; Ginantra et al., 2017; Kanten dan Darma, 2017; Wiandari dan Darma, 2017; Widiatmika dan Darma, 2018; Dewi dan Darma, 2019; Bali dan Darma, 2019; Puriati dan Darma, 2021; Hendhana dan Darma, 2017; Saefulloh dan Darma, 2014; Darma, 2005). Terlebih pula pulau Bali sangat dikenal dengan pariwisata dan budayanya, sehingga kenyamanan dan ketepatan waktu kedatangan pengunjung melalui transportasi udara harus juga menjadi perhatian serius untuk pengelolan avigasi udara dalam hal ini PERUM LPPNPI Cabang Denpasar, dan tentunya juga pengelola Bandara Udara yaitu Angkasa Pura Airport Cabang Ngurah Rai International Airport (Murti dan Darma, 2021, Yong dan Darma, 2020; Rivaldo et al., 2021; Darma et al., 2019; Asri dan Darma, 2020; Kolo dan Darma, 2020; Wardana dan Darma, 2020; Dewi dan Darma, 2019; Arsriani dan Darma, 2013; Dewi dan Darma, 2018).

Berdasarkan pemaparan diatas, peneliti tertarik untuk meneliti bagaimana persepsi maskapai penerbangan dan manajemen perum LPPNPI terhadap penerapan "Air Traffic Flow Management" sehingga mampu meningkatkan kepuasan konsumen yaitu maskapai penerbangan. 


\section{METODE PENELITIAN}

Penelitian ini adalah deskriptif kualitatif. Penelitian deskriptif yaitu penelitian yang berusaha untuk menuturkan pemecahan masalah yang ada sekarang berdasarkan data-data. Jenis penelitian deskriptif kualitatif yang digunakan pada penelitian ini dimaksudkan untuk memperoleh informasi mengenai bagaimana lika liku kesuksesan Air Traffic Flow Management di Bandar Udara Internasional Ngurah Rai Denpasar, dapat meningkatkan kepuasan Maskapai Penerbangan di Bandar Udara Internasional I Gusti Ngurah Rai Bali, sehingga mampu menghindari penumpukan pesawat di waktu tertentu, mampu mengurangi penundaan (delay), dan pesawat berputar (holding) menunggu parker, serta menghindari penumpukan penumpang di terminal Bandar Udara Internasional I Gusti Ngurah Rai Bali

Penelitian ini menggunakan teori teknik Servqual milik Zeithaml dan Bitner (2006). Dimensi-dimensi yang digunakan untuk mengetahui beberapa besar jarak harapan pelanggan dengan ekspektasi pelanggan terhadap pelayanan yang diterima dalam metode ini ada 5 yaitu tangibles, reliability, responsiveness, assurance, dan empathy.

Adapun yang Informan dalam penelitian ini adalah Maskapai Penerbangan di Bandar Udara Internasional Ngurah Rai Bali dan Manajemen Perum LPPNPI Cabang Denpasar, Serta Pelaksana Operasional Lalu lintas Penerbangan (ATC dan ATFM Officer).

Wawancara dilakukan dengan durasi rata-rata 20 menit. Wawancara direkam dengan perekam audio handphone atas ijin dari partisipan. Data dari audio tersebut kemudian diubah menjadi transkrip wawancara. Transkrip wawancara di baca dan direduksi dengan hati-hati untuk menentukan kode- kode yang dapat mewakili sekumpulan ide/pemikiran serupa. Kodekode tersebut kemudian di kelompokkan menjadi satu tema besar. Beberapa tema tersebut dan kemungkinan hubungan antar tema diidentifikasi untuk dapat merumuskan suatu model yang dapat menggambarkan fenomena yang diteliti. Keseluruhan proses ini disebut dengan proses coding dan themeing yang dilakukan dengan bantuan spreadsheet Microsoft Excel. Kutipankutipan penting yang mewakili kode tertentu di dokumentasikan dalam kolom kode yang sesuai, untuk dapat dipergunakan dalam pembahasan hasil. Agar penyusunan laporan menjadi lebih efisien, masing partisipan diberi kode: ATFM 1 A1, FDO 1 A2, Manager 1 B1, Junior Manager B2, Airlines $1 \mathrm{C} 1$. Setiap kutipan yang dipaparkan dalam pemaparan hasil diakhiri dengan kode partisipan yang menyatakan pernyataan tertentu.

\section{HASIL DAN PEMBAHASAN}

Analisis wawancara menunjukkan bahwa kepuasan pengguna /operator, kualitas ATFM dan Fungsi ATFM merupakan faktor utama yang sangat dikedepankan dalam pelayanan 
ATFM di Bandar UdaraInternasional Ngurah Rai. Kepuasan Pengguna/Operator. Berikut adalah penjelasan yang lebih detail untuk masing masing faktor tersebut.

1. Kepuasan pengguna/operator

Secara Umum Kepuasan pengguna dan Operator dalam opersai ATFM adalah baik, yang mana operator dan pengguna jasa ATFM bisa melaksanakan koordinasi dengan baik terlebih lagi sekarang koordinasi antar mereka telah dibantu sebuah system yang mengatur slot (kesediaan penerbangan) yaitu berupa aplikasi yang bernama CHRONOS, didalam CHRONOS ini pengguna jasa dan operator bisa berkoordinasi secara baik dan mengetahui dimana terdapat slot (ketersediaan) yang kosong atau penuh sehingga penumpukan pesawat secara terencana dapat terurai. Seperti yang dinyatakan oleh C1 "ATFM sangat membantu terutama terbantu oleh aplikasi CHRONOS terutama ketika pengajuan slot, terutama delay, early, pengajuan slot charter, positioning, dan lainya". Hal senada juga dinyatakan oleh A1 yaitu "ATFM yang didalam salah satunya mengatur slot penerbangan sangat membantu, karena bisa mengatur maju atau mundurnya jadwal penerbangan".

2. Tangibles

Tangibles yaitu merupakan bukti konkret kemampuan suatu perusahaan untuk menampilkan yang terbaik bagi pelanggan. Baik dari sisi fisik tampilan bangunan, fasilitas, perlengkapan, teknologi pendukung, hingga penampilan karyawan. Hal ini sudah dapat diwakilkan oleh pengelolaan ATFM di Bandar Udara Internasionl I Gusti Ngurah Rai, yang mana dikelola oleh Pengelola Jasa Penerbangan yaitu PERUM LPPNPI (AIRNAV) Cabang Denpasar sudah mampu berkoordinasi secara masih melalui digital, selain melalui aplikasi koordinasi umum seperti Whatsapp, Telegram, dan lainnya. Saat ini pengguna jasa dan operator mampu berkoordinasi melalui aplikasi yang dinamakan CHRONOS yang mana saat ini dirasakan sudah sangat membantu dan memudahkan. Hal ini sesuai dengan yang dinyatakan oleh A1 yaitu "Pengajuan slot akan lebih mudah karena adanya aplikasi CHRONOS, pengaturan sesuai batasan kapasitas".

3. Reliability

Reliability yaitu merupakan kemampuan perusahaan untuk memberikan pelayanan yang sesuai dengan harapan konsumen terkait kecepatan, waktu, tidak ada kesalahan, sikap simpatik, dan lain sebagainya. Hal ini mampu di lakukan oleh PERUM LPPNPI (AIRNAV) Cabang Denpasar khususnya dalam pelayanan ATFM karena pengguna jasa mampu mengetahui apakah keinginan mereka untuk masuk didalam slot 
(kestersediaan) itu secepat mungkin,ada indicator indicator didalam aplikasi CHRONOS yang mampu menyatakan bahwa Slot (ketersediaan) itu berwarna merah jika terisi penuh, dan bewarna hijau jika kosong sehingga secepat itu pula pihak pengguna jasa (airlines) mampu mengatur pesawatnya untuk menghindari jam jam penumpukan sehingga simbiosis mutualisme dapat terjadi antara pengguna jasa dan operator. Hal ini senada juga seperti yang dinyatakan oleh A2 "CHRONOS akan bisa lebih cepat transisinya dan mampu memperkirakan untuk waktu waktu penumpukan Pelayanannya kita mengharapkan rata, tetapi kita kembalikan ke airline karena kita sifatnya melayani mereka harapanya sih bisa mengatur tetapi juga memberikan pelayanan yang baik"

4. Responsiveness

Responsiveness yaitu merupakan tanggapan atau tanggap memberikan pelayanan yang cepat atau responsif serta diiringi dengan cara penyampaiian yang jelas dan mudah dimengerti. Pengguna jasa mampu berkoordinasi dengan unit pelayanan atfm sangat baik dan responsive, seperti yang dinyatakan oleh $\mathrm{C} 1$ yaitu "selama ini atfm personilnya kooperatif, selama itu masih ada koridor slot (ada kesepakatan).

5. Assurance

Assurance yaitu merupakan jaminan dan kepastian yang diperoleh dari sikap sopan santun karyawan, komunikasi yang baik, dan pengetahuan 9 yang dimiliki, sehingga mampu menumbuhkan rasa percaya pelanggan. Kualitas pelayanan ATFM selain terjaga dari penggunaan aplikasi yang mampu menjadi jembatan antara pengguna jasa dan operator, juga terjaga oleh sikap friendly dari operator ATFM yang bertugas sehingga juga mampu berdiskusi untuk tindakan terbaik yang diinginkan oleh pengguna jasa (Airlines). Sesuai yang dinyatakan oleh $\mathrm{C} 1$ yaitu "biasanya rekan atfm normalnya membantu dengan menaruh diujung waktu kapasitas maksimum NAC atau slot bisa dikoordinasikan selalu jika memungkinkan".

6. Emphaty

Empathy yaitu merupakan tindakan memberikan perhatian yang tulus dan bersifat pribadi kepada pelanggan, hal ini juga tercermin dalam pelayanan yang diberi oleh operator atfm yang mampu berkomunikasi secara baik dan memberitahu info terkait. Seperti yang dikatakan oleh C1 yaitu" ATFM di dps menurut saya sudah friendly, dapat menggunakan aplikasi wa”. Penelitian ini mengindikasikan bahwa perjalanan pelayanan ATFM untuk menuju salah satu tujuannya yaitu menyeimbangkan Demand dan Capacity dapat dikatakan sangat berliku awalnya dan terproses melewati masa 
masa perubahan (transisi) hingga mampu sampai di tahap saat ini yaitu lebih mampu mengurai penumpukkan pesawat udara baik di darat maupun udara, dan mampu secara terencana menjalankan strategic planningnya untuk melakukan kolaborasi aktif dengan para stakeholdernya sehingga dapat berjalan dengan baik, meskipun masih adanya kendala dapat sering ditemukan, tetapi lambat laun mulai dapat terselesaikan.

ATFM saat ini mampu menjadi langkah penting jalannya operasi penerbangan di Bandara, khususnya di Bandara Internasional I Gusti Ngurah Rai. mengapa demikian? Hal ini dikarenakan ketika ATFM mampu berjalan secara baik dan terencana, maka tercipta lah tujuan dari jalannya operasi penerbangan yaitu terjaganya keselamatan penerbangan, adanya penerbangan yang tidak menumpuk sehingga menyebabkan delay, serta yang paling penting untuk pengguna jasanya yaitu maskapai penerbangan adalah untuk menciptakan penerbangan yang tepat waktu, terkoneksi secara baik sehingga transisi penumpang antar bandara satu adan lainnya dapat terencana dan berjalan dengan baik.

ATFM merupakan hal yang harus dilakukan oleh bandara yang mempunyai tingkat pertumbuhan pergerakan pesawat udara yang tinggi, karena potensi terjadinya penumpukkan di waktu waktu tertentu dapat terdeteksi sehingga mampu dikelola dengan baik. Sifat dari ATFM itu sendiri adalah on time dan lebih ketat/"strict",karena hal ini juga mampu menjadi panduan kegiatan operasi penerbangan untuk berjalan, dan ATFM Cabang Denpasar berjalan menuju hal itu, bayangkan saja jika pengaturan Slot Penerbangan tidak berjalan dengan baik dan untuk fleksibelitas waktu tak dibatasi, pasti akan ada pengajuan yang seenaknya dan dapat dipastikan akan ada penumpukkan pesawat udara di waktu tertentu dan untuk konektivitas ke bandara selanjutnya akan terganggu dan aduan dari penumpang tentang penundaan akan sangat banyak sehingga citra maskapai penerbangan akan tidak baik.Maka dari itu kolaborasi yang aktif dari ketiga pihak yaitu pengelola jasa penerbangan, pengelola bandara, dan maskapai sangat penting dilaksanakan dalam berjalannya ATFM.

\section{PENUTUP}

Penelitian ini menunjukkan bahwa ATFM di Bandara Internasional I Gusti Ngurah Rai adalah hal yang sangat diperlukan untuk menjalankan strategi yang terencana oleh pengelola jasa penerbangan, pengelola bandara, dan maskapai penerbangan untuk menyeimbangakan antara demand (permintaan jadwal penerbangan) dengan Capacity (kapasitas ruang udara, kapasitas parker,kapasitas terminal bandara), hal ini sudah dapat dijalankan dengan baik,ini dikarenakan saat ini penumpukkan pesawat di waktu tertentu, dan keteraturan penerbangan dapat dijalankan tanpa kendala. Penelitian ini menemukan bahwa maskapai penerbangan yang 
menggunakan jasa ATFM di Bandara Internasional Ngurah Rai sudah dapatkan dikatakan puas dengan pelayanan ATFM yang sejauh ini mampu terkolaborasi dengan baik dan memudahkan dalam proses pengajuannya. Penelitian ini menemukan bahwa "proses bisnis" dari jalannya operasi penerbangan bukan hanya untuk lepas landas (takeoff), dan mendarat (landing) saja, tetapi proses berjalannya sebuah strategi yang terencana secara baik sehingga mampu menghasilkan pelayanan yang berkualitas, terejaga keselamatan penerbangannya, dan tentunya tak menumpuk. Hal ini akan membuat pelayanan maskapai penerbangan tetap ontime, penumpang pesawat udara puas, serta tujuan besarnya yaitu akan mampu melayani aktivitas penerbangan bagi wisatawan yang hendak berkunjung ke pulau bali secara masif dan terencana. Penelitian ini menggunakan teknis SERVQUAL yang menunjukkan bahwa segala aspek kualitas pelayanan sangatlah terjaga dengan baik, akan tetapi yang sangat berpengaruh untuk penelitian ini berdasarkan hasil wawancara adalah Reliabilty, mengapa demikian karena pengguna jasa dalam hal ini maskapai penerbangan puas dengan pelayanan yang ramah, cepat dan tepat waktu. Penelitian ini hanya berfokus pada pelayanan ATFM di Bandara Internasional I Gusti Ngurah Rai, sehingga masih ada batasan bagi peneliti untuk menyimpulkan kualitas pelayanan ATFM dapat tergolong baik hanya untuk di Bandara Internasional Ngurah Rai saja, besar harapan peneliti untuk adanya pengembangan penelitian kedepannya sehingga mampu menyempurnakan tujuan dari penelitian ini. 


\section{DAFTAR PUSTAKA}

Asri, A. A. S. M. A. N., \& Darma, G. S. (2020). Revealing the digital leadership spurs in 4.0 industrial revolution, International Journal of Business, Economics \& Management, 3 (1): 93-100. https://doi.org/10.31295/ijbem.v3n1.135.

Arsriani, I.A.I., and Darma, G.S. (2013). Peran Media Sosial Online Dan Komunitas Terhadap Keputusan Nasabah Bank, Jurnal Manajemen dan Bisnis, 10 (2): 48-68.

Bali, I.N.A.P., and Darma, G.S. (2019). Menguji Kesiapan Pengelolaan Desa Berbasis Manajemen Modern Guna Menghadapi Era Revolusi Industri 4.0, Jurnal Manajemen \& Bisnis, 16 (2): 1-13.

Darma, G.S., \& Noviana, I.P.T. (2020). Exploring Digital Marketing Strategies during the New Normal Era in Enhancing the Use of Digital Payment, Jurnal Mantik, 4 (3): 22572262. https://doi.org/10.35335/mantik.Vol4.2020.1084.pp2257-2262.

Darma, G.S., Wicaksono, K., Sanica, I.G., and Abiyasa, A.P. (2019). Faktor Kompensasi dan Strategi Gojek Dalam Meningkatkan Kepuasan Kerja Para Driver, JURNAL ILMIAH MANAJEMEN BISNIS DAN INOVASI UNIVERSITAS SAM RATULANGI, 6 (3): 232244.

Darma, G.S. (2005). Teknologi Informasi, Kepuasan User, Kinerja User dan Kinerja Hotel di Bali, Jurnal Ekonomi \& Bisnis, 17 (2): 93-102.

Dewi, M.V.K., and Darma, G.S. (2019). The Role of Marketing \& Competitive Intelligence In Industrial Revolution 4.0, Jurnal Manajemen \& Bisnis, 16 (1): 1-12.

Dewi, N.K.Y.W., and Darma, G.S. (2019). Strategi Investasi \& Manajemen Resiko Rumah Sakit Swasta di Bali, Jurnal Manajemen \& Bisnis, 16 (2): 110-127.

Dewi, A.A.I.S., and Darma, G.S. (2017). Proses Rekrutmen, Seleksi, Pelatihan, Penempatan dan Kinerja Karyawan, Jurnal Manajemen \& Bisnis, 14 (1): 1-18.

Dewi, N.M.A.T., and Darma, G.S. (2016). Efektivitas Leadership, Growth Performance dan Regulasi Otoritas Jasa Keuangan, Jurnal Manajemen \& Bisnis, 13 (1): 1-13.

Ginantra, K.G., Lestari, N.P.N.E., Gorda, A.A.N.E.S., and Darma, G.S. (2017). Effects of Promotion, Product Quality, Brand Image and Price on Customer Satisfaction and Brand Switching Decision, International Journal of Management and Economics Invention, 3 (12): 1514-1523.

Handayani, L.P.D.S., \& Darma, G. S. (2021). Pengaruh Kebijakan Pemeriksaan, Kebijakan Akses Informasi Keuangan dan Forensik Digital terhadap Kualitas Pemeriksaan Pajak, Syntax Literate; Jurnal Ilmiah Indonesia, 6 (3): 1260-1272.

http://dx.doi.org/10.36418/syntax-literate.v6i3.1142 
Hendhana, S., and Darma, G.S. (2017). Service Quality Rumah Sakit dan Efeknya terhadap Patient Satisfaction, Perceived Value, Trust, dan Behavioral Intention, Jurnal Manajemen \& Bisnis, 14 (1): 37-55.

ICAO. (2018). Doc 9971 Manual on Collaborative Air Traffic Flow Management (ATFM)

(Third). International Civil Aviation Organization International Civil Aviation Organization. (2016). Long-Term Traffic Forecasts. July.

ICAO. (1984). Air Traffic Services Planning Manual. In www.icao.int. International Civil Aviation Organization.

ICAO. (2016). Annex 11 Air Traffic Services (Issue July). ICAO. (2016b).

ICAO. (2016). Doc 4444 Air Traffic Management (Vol. 4444, Issue November).

Kanten, I.K., and Darma, G.S. (2017). Consumer Behaviour, Marketing Strategy, Customer Satisfaction, and Business Performance, Jurnal Manajemen \& Bisnis, 14 (2): 143165.

Kolo, S.M., and Darma, G.S. (2020). Faktor-Faktor Terpenting Yang Mempengaruhi Kepuasan dan Loyalitas Pelanggan Pengguna Jaringan 4G di Denpasar, Jurnal Manajemen Bisnis, 17 (1): 57-74.

Kotler, P., \& Garry Armstrong. (2010). Prinsip-Prinsip Pemasaran, Jilid 1 dan 2 Edisi Kedua Belas. Jakarta: Erlangga.

Kotler, P., and Kevin Lane Keller. (2016). Marketing Management, 15th Edition. New Jersey: Pearson Pretice Hall, Inc.

Murti, K.G.K., \& Darma, G. S. (2021). Jalan Terjal Online Travel Platform Hadapi Pandemi. Syntax Literate; Jurnal Ilmiah Indonesia, $6 \quad$ (5): 2280-2296. http://dx.doi.org/10.36418/syntax-literate.v6i5.2703

Moleong, L.J. (2009). Metode Penelitian Kualitatif. Bandung: Remaja Rosdakarya.

Pamungkas. O., (2018). Pengaruh Atribut Produk Dan Promosi Terhadap Kepuasan Pembelian. http://eprints.mercubuana-yogya.ac.id/id/eprint/2087.

Pearce, B. (2014). The shape of air travel markets over the next 20 years. IATA.

Priskila, S., \& Darma, G.S. (2020). Employee Perception of Brand Value in the Jewelry Industry, Journal of Economics, Business, \& Accountancy Ventura, 23 (2). http://dx.doi.org/10.14414/jebav.v23i2.2281.

Puriati, N.M. \& Darma, G.S. (2021). Menguji Kesiapan Pengelolaan Desa Wisata Berbasis Manajemen Modern Sebagai Penggerak Ekonomi Rakyat, Bisma: Jurnal Manajemen, 7 (2): 319-330. http://dx.doi.org/10.23887/bjm.v7i2.34162 
Rivaldo, I. M. G., Lestari, N.P.N.E., \& Darma, G.S., \& Gorda, A.A.N.E.S. (2021). Integrating The Credit Lending Strategies of Multi-Purpose Cooperatives (a Case Study at KSU Dauh Ayu in Denpasar), Jurnal Mantik, 4 (4): 2318-2324. https://doi.org/10.35335/mantik.Vol4.2021.1138.pp2318-2324.

Saefulloh, D.A., and Darma, G.S. (2014). Strategi Marketing Wisata Wedding Sebagai Destinasi Alternatif, Jurnal Manajemen \& Bisnis, 11 (1): 17-34.

Shavitri, L.P.D., \& Darma, G.S. (2020). Pengaruh Implementasi Kebijakan Pemeriksaan dan Forensik Digital terhadap Kualitas Pemeriksaan dan Keberhasilan Penerimaan Pajak, $\begin{array}{llllll}\text { E-Jurnal } & \text { Akuntansi, } & 30 & (10): & 2682 & -\end{array}$ https://doi.org/10.24843/EJA.2020.v30.i10.p19

Sudiwedani, A., \& Darma, G.S. (2020). Analysis of the effect of knowledge, attitude, and skill related to the preparation of doctors in facing industrial revolution 4.0, Bali Medical Journal, 9 (2): 524-530. https://dx.doi.org/10.15562/bmj.v9i2.1895.

Schiffman dan Kanuk. (2008). Perilaku konsumen. Edisi 7. Jakarta: Indeks.

Sugiyono. (2019). Metode Penelitian Kuantitatif, Kualitatif dan R\&D. Bandung: Alfabeta.

Tjiptono, Fandy. (2011). Strategi Pemasaran. Edisi 3. Yogyakarta : ANDI.

Wardana, I.M.A., \& Darma, G.S. (2020). Garment Industry Competitive Advantage Strategy During Covid-19 Pandemic, PalArch's Journal of Archaeology of Egypt / Egyptology, https://www.archives.palarch.nl/index.php/jae/article/view/2732.

Widana, I.W., and Darma, G.S. (2018). Branding Denpasar Smart City Guna Meningkatkan Kunjungan Wisatawan, Jurnal Manajemen \& Bisnis, 15 (1): 176-199.

Wiandari, I.A.A., and Darma, G.S. (2017). Kepemimpinan, Total Quality Management, Perilaku Produktif Karyawan, Kinerja Karyawan dan Kinerja Perusahaan, Jurnal Manajemen \& Bisnis, 14 (2): 61-78.

Widiatmika, P.H., and Darma, G.S. (2018). Good Corporate Governance, Job Motivation, Organization Culture Which Impact Company Financial Performance, Jurnal Manajemen \& Bisnis, 15 (3): 82-99.

Yudhistira, T., and Darma, G.S. (2020). Menakar Plus Minus Penerapan Corporate Social Responsibility (CSR) di Industri Jasa Penerbangan, Jurnal Manajemen Bisnis, 17 (1): $1-11$.

Yong, I.D., \& Darma, G.S. (2020). Indikator Penentu Naik Turunnya Harga Saham pada Perusahaan High Deviden 20 Periode Tahun 2014-2019, Syntax Literate ; Jurnal Ilmiah Indonesia, 5 (12): 1591-1610. doi:10.36418/syntax-literate.v5i12.1907 